\title{
DRUG INTERACTIONS FOR ELDERLY WITH RESPIRATORY DISORDERS AND TIMES OF COVID-19: A SYSTEMATIC SCOPING REVIEW
}

\author{
INTERACCIONES FARMACOLÓGICAS PARA ANCIANOS CON ENFERMEDADES \\ RESPIRATORIAS YTIEMPOS DE COVID-19: UNA REVISIÓN SISTEMÁTICA DEL ALCANCE
}

\author{
Marcela FORGERINI, ${ }^{10}$ Geovana SCHIAVO ${ }^{2}{ }^{\circledR}$, Rosa Camila LUCCHETTA ${ }^{3 \oplus}$, \\ Patrícia de CARVALHO MASTROIANNI ${ }^{\star 4}$
}

Received: 12 September 2020. Approved: 8 November 2020

\begin{abstract}
Background: The elderly people have high morbimortality associated with respiratory disorders, in addition to the presence of other safety risk factors, such as the use of potentially inappropriate medication and the occurrence of drug interactions. Objective: Considering the current pandemic scenario, it was intended to identify explicit criteria-based tools that reported drug interactions between potentially inappropriate medication and respiratory system disorders and possibly worse prognosis of COVID-19 infection. Methods: A systematic scoping review was conducted until February 2020. Study characteristics of explicit criteria-based tools, and potentially inappropriate medication, drug interactions, and therapeutic management, were extracted. Results: Nineteen explicit criteria-based tools were included. Nineteen drug interactions and 17 potentially inappropriate medications with concerns for three respiratory disorders (asthma, chronic pulmonary obstructive disease, and respiratory failure) were identified. The most frequent pharmacological classes reported were benzodiazepines and betablockers. For clinical management, the tools recommend using cardioselective beta-blockers, calcium channel blockers, angiotensin-converting enzyme inhibitors, and angiotensin II type I receptor blockers and benzodiazepines with a short or intermediate half-life. Conclusion: Considering the increased risk of COVID-19 infection in the elderly, drug interactions and the use of potentially inappropriate medication associated with the occurrence of adverse drug events in the respiratory system may also worsening COVID-19 infection in patients with uncontrolled respiratory disorders. Thus, it is essential to assess drug therapy in use, to identify safety risks and monitor the elderly in general and those with a worse prognosis concerning COVID-19, promoting patient safety.

Keywords: Coronavirus Infections,; Contraindications, Drug; Drug-Related Effects and Adverse Reactions; Inappropriate Prescribing; Older Adults; Potentially Inappropriate Medication List; Patient Safety; Respiratory Tract Diseases.

PhD Student. Department of Drugs and Medicines, School of Pharmaceutical Sciences, São Paulo State University (UNESP), Araraquara, Brazil.

2 Graduate Student. Department of Drugs and Medicines, School of Pharmaceutical Sciences, São Paulo State University (UNESP), Araraquara, Brazil.

3 PhD. Department of Drugs and Medicines, School of Pharmaceutical Sciences, São Paulo State University (UNESP), Araraquara, Brazil.

${ }_{4} \mathrm{PhD}$. Associate Professor. Department of Drugs and Medicines, Faculty of Pharmaceutical Sciences, São Paulo State University (UNESP), Araraquara, Brazil.

* Corresponding author: patricia.mastroianni@unesp.br
\end{abstract}




\section{RESUMEN}

Antecedentes: Los ancianos tienen alta morbimortalidad asociada a trastornos respiratorios, además de la presencia de otros factores de riesgo de seguridad, como el uso de medicación potencialmente inapropiada y la ocurrencia de interacciones medicamentosas. Objetivo: Teniendo en cuenta el escenario pandémico actual, se pretendía identificar herramientas explícitas basadas en criterios que informaran interacciones farmacológicas entre medicamentos potencialmente inapropiados y trastornos del sistema respiratorio y posiblemente un peor pronóstico de la infección por COVID-19. Métodos: Se realizó una revisión sistemática del alcance hasta febrero de 2020. Se extrajeron las características del estudio de las herramientas explícitas basadas en criterios y la medicación potencialmente inapropiada, las interacciones entre medicamentos y el manejo terapéutico. Resultados: Se incluyeron diecinueve herramientas explícitas basadas en criterios. Se identificaron diecinueve interacciones farmacológicas y 17 medicamentos potencialmente inapropiados con preocupaciones por tres trastornos respiratorios (asma, enfermedad pulmonar obstructiva crónica e insuficiencia respiratoria). Las clases farmacológicas más frecuentes comunicadas fueron las benzodiacepinas y los betabloqueantes. Para el manejo clínico, las herramientas recomiendan el uso de betabloqueantes cardioselectivos, bloqueadores de los canales de calcio, inhibidores de la enzima convertidora de angiotensina y bloqueadores del receptor de angiotensina II tipo I y benzodiacepinas con una vida media corta o intermedia. Conclusión: Teniendo en cuenta el mayor riesgo de infección por COVID-19 en los ancianos, las interacciones farmacológicas y el uso de medicamentos potencialmente inapropiados asociados con la aparición de eventos farmacológicos adversos en el sistema respiratorio también pueden empeorar la infección por COVID-19 en pacientes con trastornos respiratorios no controlados. Por tanto, es fundamental evaluar la farmacoterapia en uso, identificar los riesgos de seguridad y monitorizar a los ancianos en general y a aquellos con peor pronóstico en relación con el COVID-19, promoviendo la seguridad del paciente.

Palabras clave: Anciano; Contraindicaciones de los Medicamentos; Efectos Colaterales y Reacciones Adversas Relacionados con Medicamentos; Enfermedades Respiratorias; Gestión de Riesgos; Infecciones por Coronavirus; Lista de Medicamentos Potencialmente Inapropiados; Prescripción Inadecuada.

\section{INTRODUCTION}

Respiratory disorders are associated with risk of hospital admission (1), high economic burden, costs to the health system, and costs with drug acquisition $(2,3)$, in addition, to be suggested as risk factors for the low quality of life in elderly people (4).

The world has been currently experiencing the new pandemic caused by the severe acute respiratory syndrome coronavirus 2 (SARS-CoV-2) and COVID-19 (5). Studies have raised hypotheses that older people and the presence of comorbidities, such as other respiratory system disorders, high blood pressure, and diabetes mellitus, make the population more vulnerable to being affected by the COVID-19 infection (6). Furthermore, the presence of these risk factors can be associated with a more severe manifestation of the COVID-19 infection, which may require mechanical ventilation and admission to the intensive care unit, which finally may evolve to death (7-9).

Recent experience also suggests that the presence of uncontrolled comorbidities contributes to the poor prognosis of COVID-19 in the elderly. (10). Therefore, in the scope of patient safety, the most effective strategy is the monitoring and control of comorbidities considered to be risk factors to COVID-19 infection (7). Nevertheless, adequate management of comorbidities can be impaired in the elderly due to the aging process and the presence of multimorbidity (11) and polymedication (12), which may favor the prescription of potentially inappropriate medications (13), the occurrence of drug interactions (14), and adherence issues (15).

The prescription and use of potentially inappropriate medications among elderly people with respiratory disorders are frequent. It was found that about $55 \%$ of the elderly diagnosed with chronic obstructive pulmonary disease (COPD) or asthma were in use of inappropriate medications at hospital admission (16). Besides, a Brazilian followup study identified that seven in every ten elderly people diagnosed with COPD were in use of at least one inappropriate medication (17). 
In this context, a recent review reported drug interactions and potentially inappropriate medication in older adults with mental and behavioral disorders (18); however, little is known regarding the elderly with respiratory disorders. Therefore, considering the burden associated with respiratory disorders $(2,3)$, the high prevalence and mortality among elderly people with these disorders (5), the international concern with COVID-19 (5), the frequent use of potentially inappropriate medications, and others safety risks associated (16), a systematic scoping review was conducted to identify drug interactions, of potentially inappropriate medications, with respiratory disorders reported by explicit potentially inappropriate medications criteria-based tools.

\section{METHODS}

A systematic scoping review was conducted following the recommendations of the Joanna Briggs Institute guidelines (21) and of Cochrane Collaboration (Cochrane Handbook for Systematic Reviews of Interventions) (20) which guide the processes for data extraction and synthesis. Furthermore, PRISMA-ScR (Preferred Reporting Items for Systematic reviews and Meta-Analyzes extension for Scoping Reviews) was considered for this reporting (22).

The protocol of this systematic scoping review was previously outlined and published (19).

\section{Search strategy and selection criteria}

This systematic scoping review included studies that developed and/or validated explicit potentially inappropriate medications criteria-based tools for older adults and reported potentially inappropriate medications and/or drug interactions involving respiratory disorders. Moreover, potentially inappropriate medications with concerns and adverse drug reactions related to respiratory diseases, and therapeutic management were considered. There was no limitation on publication time, the country in which the tools were developed, level of health care or professional involved in potentially inappropriate medications and/or drug interaction definition or assessment.

The search strategy was carried out on PubMed and Scopus in February 2020. The search strategy, including all identified keywords and descriptors, was adapted for each database included and detailed in table 1 of supplementary material from reference 23. Articles written in non-Roman characters (i.e., Russian, Japanese, Chinese) were excluded during selection process.

Clinical trials, observational studies, and studies conducted by a panel of experts who proposed explicit potentially inappropriate medications criteria-based tools were considered. Editorials, commentaries, letters, news, abstracts from conference proceedings, theses and dissertations, implicit criteria, old versions of the tool, and drugs no longer marketed on the world were excluded.

For manual search, the reference lists of included articles and previously identified reviews were searched.

\section{Studies selection, extraction, and data presentation}

The identified records were imported in EndNote version X 7.2.1 (Clarivate Analytics, PA, USA) and exported to spreadsheets to recording the exclusion reasons. Two authors (M.F. and G.S.) performed the study selection process independently. Disagreements among authors at each selection stage were resolved through consensus discussion or with a third author (R.C.L.).

The data were extracted by two independent reviewers (M.F. and G.S.), using Microsoft Office Excel spreadsheets or Microsoft Office Word (Microsoft, Redmond, WA, USA). The extracted data included specific details about (i) characteristics of studies; (ii) distribution of tools by year and country; and (iii) potentially inappropriate medications, drug interactions, concerns, and therapeutic management (e.g., deprescription, therapeutic equivalent) according to the tools. Potentially inappropriate medications were classified according to commercialization and essentiality by Rename (Brazil) and WHO (world).

The results are presented in a narrative form and tables to assist in the presentation of the data.

Following the recommendations of the Joanna Briggs Institute (21), the methodological quality assessment was not carried out because, conversely to systematic reviews aimed at assessing effects, systematic scoping reviews aim to group all available evidence on a specific subject, regardless of methodological quality. 
Table 1. Description of explicit potentially inappropriate medications criteria-based tools and drug interactions between potentially inappropriate medications and asthma, chronic obstructive pulmonary disease, and respiratory failure.

\begin{tabular}{|c|c|c|c|c|c|c|c|c|}
\hline $\begin{array}{l}\text { Explicit potentially inappropriate } \\
\text { medications criteria-based tools }\end{array}$ & $\underbrace{2}_{0}$ & 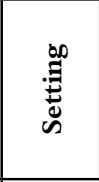 & $\begin{array}{l}\text { Tool } \\
\text { development } \\
\text { technique }\end{array}$ & 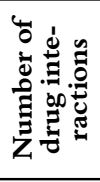 & 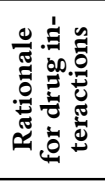 & $\begin{array}{l}\text { Proposal } \\
\text { of mana- } \\
\text { gement } \\
\text { for drug } \\
\text { interac- } \\
\text { tions } \\
\end{array}$ & $\begin{array}{c}\text { Inappropriate } \\
\text { medication } \\
\text { with concerns } \\
\text { for respiratory } \\
\text { disorders }\end{array}$ & $\begin{array}{c}\text { Proposal of } \\
\text { therapeutic } \\
\text { management for } \\
\text { inappropriate } \\
\text { medication }\end{array}$ \\
\hline Updating Beers criteria, 2003 (55) & US & NR & LR; DP-1R; DIS & 6 & 6 & 0 & 0 & 0 \\
\hline Thai criteria, $2008(56)$ & THAI & NR & LR; DP-3R & 6 & 6 & 0 & 1 & 0 \\
\hline Kim criteria b, $2010(57)$ & $\mathrm{KR}$ & $\mathrm{AMB}$ & PIM-I; DP-2R & 4 & 4 & 4 & 0 & 0 \\
\hline Mimica criteria, 2012 (58) & $\mathrm{CRO}$ & NR & PIM-I & 4 & 2 & 4 & 0 & 0 \\
\hline Mann criteria, 2012 (59) & AT & NR & DP-2R; DIS & 0 & 0 & 0 & 3 & 2 \\
\hline Fialová criteria, 2013 (60) & $\mathrm{CZ}$ & HOSP & DP-3R & 7 & 7 & 1 & 0 & 0 \\
\hline Clyne criteria, 2013 (61) & IE & AMB & LR; PIM-I; CS & 1 & 1 & 1 & 0 & 0 \\
\hline $\begin{array}{l}\text { STOPP/START Spanish version, } \\
2015 \text { (62) }\end{array}$ & ES & NR & PIM-I & 1 & 1 & 0 & 0 & 0 \\
\hline STOPP/START v2, 2015 (63) & IE & NR & PIM-I; DP-2R & 1 & 1 & 0 & 0 & 0 \\
\hline GheOP3S tool, 2015 (64) & $\mathrm{BE}$ & AMB & LR; DP-2R & 2 & 0 & 2 & 0 & 0 \\
\hline The EU(7)-PIM list, 2015 (65) & EUR & NR & LR; DP-2R & 0 & 0 & 0 & 3 & 3 \\
\hline STOPP/START Japanese, 2016 (66) & $\mathrm{JP}$ & NR & LR; DIS & 0 & 0 & 0 & 5 & 5 \\
\hline Poudel criteria, $2016(67)$ & AUS & LTI & PIM-I; LR & 0 & 0 & 0 & 1 & 1 \\
\hline $\begin{array}{l}\text { Brazilian Consensus of Potentially } \\
\text { Inappropriate Medicines for the } \\
\text { Elderly (68) }\end{array}$ & $\mathrm{BR}$ & NR & PIM-I; DP-2R & 1 & 1 & 0 & 1 & 0 \\
\hline Korean List, 2018 (69) & $\mathrm{KR}$ & NR & PIM-I; DP-4R & 1 & 0 & 0 & 0 & 0 \\
\hline Lista IFAsPIAM, 2018 (70) & $\mathrm{AR}$ & NR & LR; DP-3R & 0 & 0 & 0 & 6 & 5 \\
\hline STOPP/START Sri Lanka, 2019 (71) & $\mathrm{SL}$ & NR & PIM-I; DP & 1 & 0 & 0 & 0 & 0 \\
\hline Gonzalez criteria, 2019 (72) & ES & NR & LR; DP-2R & 0 & 0 & 0 & 1 & 0 \\
\hline Chang criteria, 2019 (73) & TW & NR & LR; DP-2R & 2 & 2 & 0 & 0 & 0 \\
\hline
\end{tabular}

Explicit potentially inappropriate medications criteria-based tools: EU: European union; GheOP3S: Ghent Older People's Prescriptions community Pharmacy Screening; IFAsPIAM: Ingredientes Farmacéuticos Activos Potencialmente Inapropiados en Adultos Mayores (in English, Potentially Inappropriate Active Pharmaceutical Ingredients in Older Adults); PIM: potentially inappropriate medications; STOP/START: Screening Tool of Older Persons' Prescriptions/ Screening Tool to Alert to Right Treatment; US: United States; Title: ADE: adverse drugs event; Country: AR: Argentina; AT: Austria; AUS: Australia; BE: Belgium; BR: Brazil; CRO: Croatia; CZ: Czech republic; ES: Spain; EUR: Europe; IE: Ireland; JP: Japan; KR: Korea; SL: Sri Lanka; THAI: Thailand; TW: Taiwan; Population: ELD: Elderly in general; Setting: AMB: Ambulatorial; HOSP: Hospital; LTI: Long Term Institutions; NR: Not reported. Tool development technique: CS: Case-study; DIS: Discussion with the experts; DP: Delphi panel without number of rounds; DP-1R: Delphi panel 1-round; DP-2R: Delphi panel 2-rounds; DP-3R: Delphi panel 3-rounds; DP-4R: Delphi panel 4-rounds; LR: Literature review

\section{RESULTS}

This systematic scoping review identified 2,370 records after removing duplicates, and ten records were included after a manual search. 2,273 records were considered irrelevant during screening, and 53 were excluded in the full-text evaluation. Although 54 records were considered relevant, only 19 reported drug interactions from potentially inappropriate medications and respiratory disorders and potentially inappropriate medications with concerns for the respiratory system. Therefore, 19 explicit potentially inappropriate medications criteria-based tools were included and are described in Table 1. The supplementary data of this manuscript was published in a public repository and available in the reference 23 .

The tools identified were published between 2003 and 2019; developed on the European $(n=10)$, Asian $(n=5)$, American $(n=3)$, and Oceania $(n=1)$ continents; and for the elderly in general, without specific morbidities or clinical conditions.

Nineteen drug interactions between potentially inappropriate medications and respiratory disorder were identified. Although the International Classification of Diseases (ICD-10) for respiratory disorders comprises 100 morbidities, the tools reported drug interactions involving three morbidities, namely: asthma, COPD, and respiratory failure (Table 2). 
Table 2. Description of drug interaction of potentially inappropriate medication and three morbidities of respiratory system (asthma, chronic obstructive pulmonary disease, and respiratory failure), rationale, and therapeutic management proposal.

\begin{tabular}{|c|c|c|}
\hline $\begin{array}{c}\text { Drug/Pharmacological class [n of tool] } \\
\text { (reference) }\end{array}$ & $\begin{array}{c}\text { Rationale, related risks, and/or adverse } \\
\text { drug events }\end{array}$ & $\begin{array}{l}\text { Therapeutic management proposed the } \\
\text { by tools }\end{array}$ \\
\hline \multicolumn{3}{|l|}{ Asthma } \\
\hline Benzodiazepines [2] $(56,58)$ & $\begin{array}{l}\text { Worsening of asthma and respiratory depres- } \\
\text { sion }(56,58)\end{array}$ & $\begin{array}{l}\text { Benzodiazepines (short or intermediate half- } \\
\text { life) (58) }\end{array}$ \\
\hline Beta-blockers [6] $(56-58,60,64,73)$ & $\begin{array}{l}\text { Worsening of respiratory diseases; heart fail- } \\
\text { ure; mucus production }(57,58,60,64,73) \text {; and } \\
\text { bronchoconstriction due to B2 antagonistic } \\
\text { effects (56) }\end{array}$ & $\begin{array}{l}\text { Cardioselective beta-blockers; and other } \\
\text { pharmacological class of antihypertensive } \\
\text { drugs }(57,58,64)\end{array}$ \\
\hline Mucolytics [1] (58) & Increasing mucus production (58) & Not reported \\
\hline \multicolumn{3}{|c|}{ Chronic obstructive pulmonary disease (COPD) } \\
\hline Antiasthmatics [1] (69) & Not reported & Not reported \\
\hline Antitussives [1] (60) & Increasing mucus production $(60)$ & Not reported \\
\hline Benzodiazepines [4] $(56,58,60,71)$ & $\begin{array}{l}\text { Worsening of respiratory depression } \\
(56,58,60,71)\end{array}$ & $\begin{array}{l}\text { Benzodiazepines (short or intermediate half- } \\
\text { life) (58) }\end{array}$ \\
\hline $\begin{array}{l}\text { Benzodiazepines: chlorazepate, } \\
\text { clodiazepoxide, diazepam, halazepam, } \\
\text { quazepam [1] (55) }\end{array}$ & $\begin{array}{l}\text { Induce or exacerbate respiratory depression; } \\
\text { adverse drug reactions in the central nervous } \\
\text { system (55) }\end{array}$ & Not reported \\
\hline $\begin{array}{l}\text { Benzodiazepines: chlorazepate, diazepam } \\
\text { [1] (57) }\end{array}$ & $\begin{array}{l}\text { Induce or exacerbate respiratory depression; } \\
\text { adverse drug reactions in the central nervous } \\
\text { system (57) }\end{array}$ & Non-pharmacological therapy (57) \\
\hline Beta-blockers [7] $(56-58,60,64,68,73)$ & $\begin{array}{l}\text { Bronchospasm; worsening of respiratory de- } \\
\text { pression; worsening of respiratory symptoms } \\
\text { (57,58,60,64,68,73); bronchoconstriction due } \\
\text { to B2 antagonistic effects ( } 56 \text { ) }\end{array}$ & $\begin{array}{l}\text { Calcium channel blockers; cardioselective } \\
\text { beta-blockers; another pharmacological class } \\
\text { of antihypertensive drugs }(57,58,64)\end{array}$ \\
\hline Beta-blockers: propranolol [1] (55) & $\begin{array}{l}\text { Induce or exacerbate respiratory depression; } \\
\text { adverse drug reactions in the central nervous } \\
\text { system (55) }\end{array}$ & Not reported \\
\hline Mucolytica [1] (60) & Increasing of mucus production (60) & Not reported \\
\hline Systemic corticosteroids [1] (61) & Systemic adverse drug reactions (61) & Inhaled corticosteroids (61). \\
\hline \multicolumn{3}{|l|}{ Respiratory insufficiency } \\
\hline Benzodiazepines [2] $(62,63)$ & Worsening of respiratory depression $(62,63)$ & Not reported \\
\hline Biguanides: metformin [1] (60) & Toxicity; lactic acidosis $(60)$ & Not reported \\
\hline
\end{tabular}

$\mathrm{N}$ : number of tools that reported drug interactions of each pharmacological class with a respiratory disorder.

The most frequent pharmacological classes involved in the drug interactions were betablockers $(n=11)$ and benzodiazepines $(n=8)$, and the drugs clorazepate $(\mathrm{n}=2)$ and diazepam $(n=2)$, both of benzodiazepines pharmacological class. The possible rationale and the mechanism for the occurrence of the drug interactions were reported for 18 of the 19 drug interactions found, with increased mucus production leading to bronchoconstriction due to antagonistic effects on B2 receptors, worsening respiratory diseases, and respiratory depression being the most frequent.

Despite there is no therapeutic management proposal for the potentially inappropriate medications involved in 15 drug interactions, the tools reported some options for managing betablockers and benzodiazepines. Regarding betablockers, the tools recommended the replacement for cardioselective beta-blockers, calcium channel blockers, angiotensin-converting enzyme inhibitors, and angiotensin II type I receptor blockers or another class of antihypertensive drugs. For benzodiazepines, it is recommended the use of short or intermediate half-life benzodiazepines. The rationale and therapeutic management reported in the tools for the drug interactions, and potentially inappropriate medication are described in Table 2.

Eight tools reported 17 potentially inappropriate medications with concerns for the respiratory system. The drugs most frequently reported were phenobarbital $(n=3)$, propranolol $(n=2)$, and theophylline $(n=2)$, all associated with respiratory depression, exacerbation of the respiratory disorder, and induction of asthmatic attacks. Clinical monitoring of possible adverse drug events from phenobarbital use is recommended and, when 
possible, the use of antiepileptics (lamotrigine, valproic acid, levetiracetam, and gabapentin) is preferable. Angiotensin-converting enzyme inhibitors, angiotensin II type I receptor blockers, selective beta-blockers, and diuretics should be considered instead of propranolol. Besides, carvedilol may be the best choice in heart failure complicated by COPD. No pharmacotherapeutic equivalent was reported for theophylline, however, cardiac function monitoring is strongly recommended due to this drug's narrow therapeutic range. When possible, monitoring this drug's use to identify possible adverse drug events and starting non-pharmacological treatment was recommended (Table 3 and Figure 1).

Twenty-two drugs and nine pharmacological classes were reported in drug interaction and/ or associated with adverse drug events with respiratory disorders. Among them, nine and eight drugs and nine pharmacological classes are standard as essential in the world (WHO) and Brazil (Rename), respectively. Besides, the tools proposed 22 therapeutic equivalents for the potentially inappropriate medication identified, being 18 standards as essential by Rename and 16 by WHO (Tables 3 and 4).
The tools identified were published between 2003 and 2019; developed on the European $(n=10)$, Asian $(n=5)$, American $(n=3)$, and Oceania $(n=1)$ continents; and for the elderly in general, without specific morbidities or clinical conditions.

Nineteen drug interactions between potentially inappropriate medications and respiratory disease were identified. Although the International Classification of Diseases (ICD-10) for respiratory disorders comprises 100 morbidities, the tools reported drug interactions involving three morbidities, namely: asthma, COPD, and respiratory failure (Table 2).

The most frequent pharmacological classes involved in the drug interactions were betablockers $(n=11)$ and benzodiazepines $(n=8)$, and the drugs clorazepate $(n=2)$ and diazepam $(n=2)$, both of benzodiazepines pharmacological class. The possible rationale and the mechanism for the occurrence of the drug interactions were reported for 18 of the 19 drug interactions found, with increased mucus production leading to bronchoconstriction due to antagonistic effects on B2 receptors, worsening respiratory diseases, and respiratory depression being the most frequent.

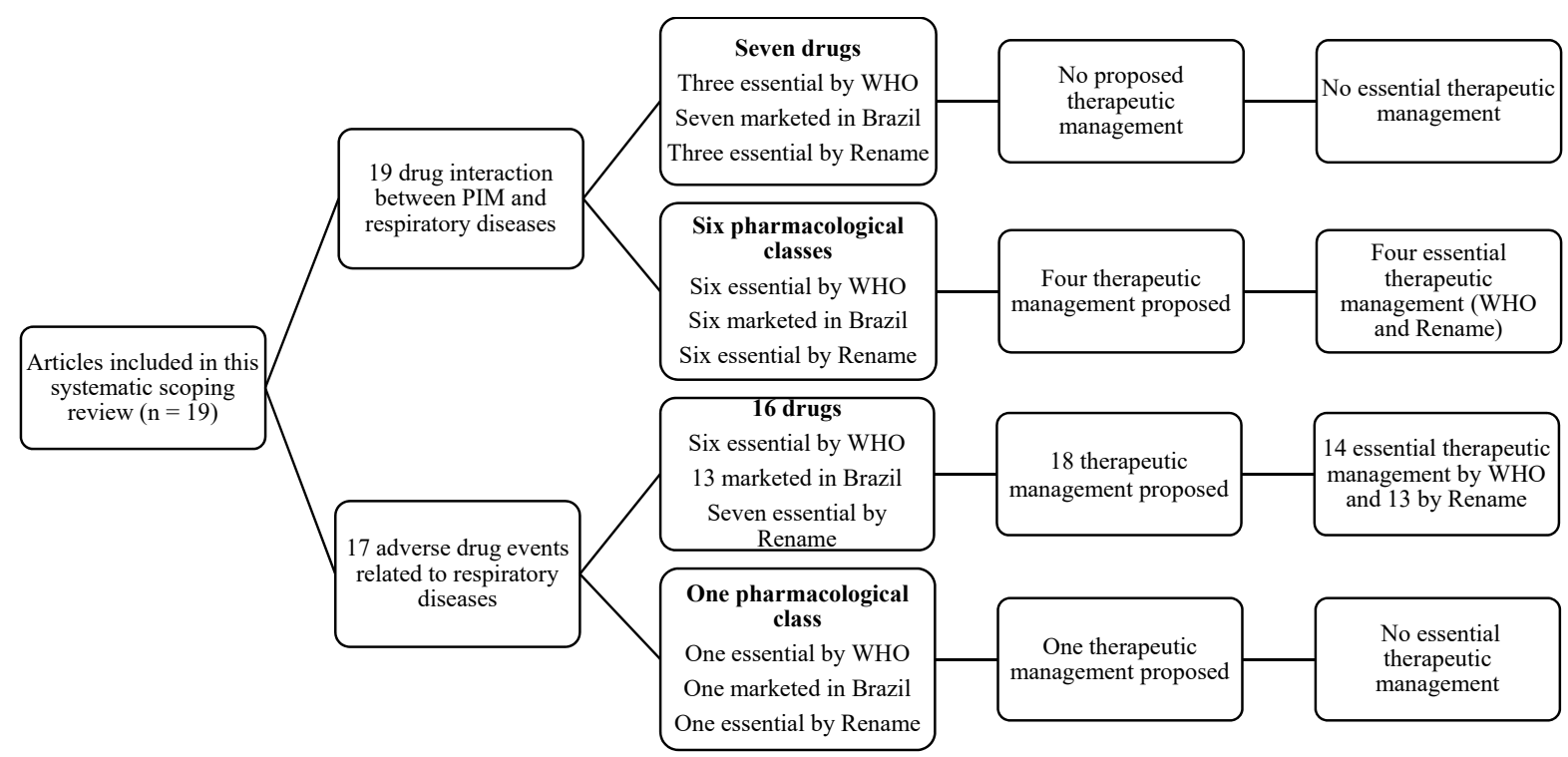

Figure 1. Drug interactions and adverse drug events related to respiratory disorders drugs, and pharmacological classes.

Rename: National List of Essential Medicines; WHO: List of Essential Medicines by World Health Organization; PIM: potentially inappropriate medication. 
Table 3. Inappropriate pharmacological classes and drugs with concerns for elderly people with respiratory disorders according to explicit potentially inappropriate medications criteria-based tools, rationale and therapeutic management proposal.

\begin{tabular}{|c|c|c|}
\hline $\begin{array}{l}\text { Drug/Pharmacological class } \\
\text { [n of tool] (reference) }\end{array}$ & $\begin{array}{c}\text { Rationale, related risks, and/or adverse } \\
\text { drug events }\end{array}$ & $\begin{array}{l}\text { Therapeutic management proposed by } \\
\text { the tools }\end{array}$ \\
\hline Betamethasone [1] (66) & $\begin{array}{l}\text { Respiratory muscle weakness; respiratory } \\
\text { failure; development of peptic ulcers (66) }\end{array}$ & Not reported \\
\hline Buprenorphine [1] (70) & $\begin{array}{l}\text { Dizziness, sedation; nausea, vomiting, } \\
\text { constipation; euphoria, dysphoria, } \\
\text { convulsions; hallucinations; respiratory } \\
\text { depression (70) }\end{array}$ & Not reported \\
\hline Carteolol [1] (66) & $\begin{array}{l}\text { Exacerbate of respiratory disease; inducing of } \\
\text { asthmatic attacks (66) }\end{array}$ & $\begin{array}{l}\text { For asthma or COPD: selective beta-blockers } \\
\text { for } \beta 1 \text { receptors. Carvedilol can be used for } \\
\text { heart failure complicated by COPD (66) }\end{array}$ \\
\hline Clomethazole [1](65) & Respiratory depression (65) & Adjust dose (500-1000 mg at bedtime) (65) \\
\hline Codeine [1] (65) & $\begin{array}{l}\text { Hypotension; sweating; constipation, vomit- } \\
\text { ing; dizziness, sedation; and respiratory de- } \\
\text { pression in treatments longer than two weeks } \\
(65)\end{array}$ & $\begin{array}{l}\text { Adjust of dose. For pain management: } \\
\text { non-steroidal anti-inflammatory and anti- } \\
\text { rheumatic (65) }\end{array}$ \\
\hline Dextropropoxyphene ([1] (70) & $\begin{array}{l}\text { Dizziness, sedation; nausea; vomiting; con- } \\
\text { stipation; euphoria, dysphoria; convulsions; } \\
\text { hallucinations; respiratory depression (70) } \\
\end{array}$ & $\begin{array}{l}\text { Paracetamol; codeine; and ibuprofen. It is } \\
\text { recommend the use for a short period of time } \\
\text { and associated to a gastric protection (70) }\end{array}$ \\
\hline Fentanyl [1] (72) & Respiratory depression (72) & Not reported \\
\hline Hypnotics [1] (59) & $\begin{array}{l}\text { Amnesia; prolonged sedation; cognitive im- } \\
\text { pairment; ataxia; hypotension; falls; respira- } \\
\text { tory depression; (59) }\end{array}$ & Z-drugs (59) \\
\hline Meperidine [1] (59) & $\begin{array}{l}\text { Seizures, delirium, sedation; Respiratory } \\
\text { depression (59) }\end{array}$ & Hydromorphone (59) \\
\hline Methylprednisolone [1] (66) & $\begin{array}{l}\text { Respiratory muscle weakness; respiratory fail- } \\
\text { ure; risk of development of peptic ulcers (66). }\end{array}$ & $\begin{array}{l}\text { If the use is necessary, consider } 40 \mathrm{mg} \text { of pred- } \\
\text { nisolone per day for five days (66). }\end{array}$ \\
\hline Nitrofurantoin [1] (67) & $\begin{array}{l}\text { Adverse pulmonary events; renal impairment; } \\
\text { liver damage (67) }\end{array}$ & $\begin{array}{l}\text { Cephalosporins; cotrimoxazole; and trim- } \\
\text { ethoprim are preferable. The prescription of } \\
\text { antibiotics should be according to your sensi- } \\
\text { tivity (67) }\end{array}$ \\
\hline Pentobarbital [1] (70) & $\begin{array}{l}\text { Overdose; respiratory depression; cognitive } \\
\text { impairment; psychiatric reactions (agitation, } \\
\text { irritability, hallucinations, psychosis); falls and } \\
\text { fractures (70) }\end{array}$ & $\begin{array}{l}\text { Short or intermediate half-life benzodiaz- } \\
\text { epines are preferable }(70)\end{array}$ \\
\hline Phenobarbital [3] $(56,59,70)$ & $\begin{array}{l}\text { Dependence; central nervous system } \\
\text { depression,(sedation, breath suppression); } \\
\text { cognitive impairment; drowsiness; memory } \\
\text { impairment; paradoxical reaction; irritability; } \\
\text { falls and fractures; dyskinesia; ataxia; respira- } \\
\text { tory depression }(56,59,70)\end{array}$ & $\begin{array}{l}\text { Other antiepileptic drugs (e.g. lamotrigine, } \\
\text { valproic acid, levetiracetam, gabapentin). } \\
\text { Clinical monitoring of adverse reactions (gait } \\
\text { stability test, coordination; psychopathology) } \\
\text { and therapeutic monitoring are recommended } \\
\text { (70) }\end{array}$ \\
\hline Prednisolone [1] (66) & $\begin{array}{l}\text { Respiratory muscle weakness; respiratory } \\
\text { failure; development of peptic ulcers (66) }\end{array}$ & If necessary, 40mg per day (66) \\
\hline Propranolol [2] $(65,66)$ & $\begin{array}{l}\text { Exacerbate or cause respiratory depression; } \\
\text { induction of asthmatic attacks; adverse events } \\
\text { in the central nervous system }(65,66)\end{array}$ & $\begin{array}{l}\text { If necessary, use three doses of } 20 \mathrm{mg} \text { daily. } \\
\text { Cardioselective beta-blockers; angiotensin- } \\
\text { converting enzyme inhibitors; diuretics are } \\
\text { recommended. For bronchial asthma or } \\
\text { COPD: selective beta-blockers for } \beta 1 \text { recep- } \\
\text { tors. Carvedilol can be used for heart failure } \\
\text { complicated by COPD }(65,66) \text {. }\end{array}$ \\
\hline Theophylline [2] $(68,70)$ & $\begin{array}{l}\text { Arrhythmias; adverse drug reactions due to } \\
\text { their narrow therapeutic range; controversial } \\
\text { efficacy in COPD patients }(68,70)\end{array}$ & Monitoring of cardiac function (70) \\
\hline Thiopental [1] (70) & $\begin{array}{l}\text { Overdose; respiratory depression; cognitive } \\
\text { impairment, psychiatric reactions (agitation, } \\
\text { irritability, hallucinations, psychosis); falls and } \\
\text { fractures (70) }\end{array}$ & $\begin{array}{l}\text { Lower dosage of short half-life benzodiaz- } \\
\text { epine (70) }\end{array}$ \\
\hline
\end{tabular}

COPD: chronic obstructive pulmonary disease; N: number of tools that reported each pharmacological class with adverse drug event related to respiratory disorder 
Table 4. Essentiality of therapeutic equivalent proposed for potentially inappropriate medications for the elderly with respiratory disorders, according to National List of Essential Medicines (Rename - Brazil) and List of Essential Medicines (World Health Organization).

\begin{tabular}{|c|c|c|c|c|c|c|}
\hline \multirow[b]{2}{*}{$\begin{array}{c}\text { Inappropriate drugs } \\
\text { and pharmacological } \\
\text { classes }\end{array}$} & \multicolumn{3}{|c|}{$\begin{array}{c}\text { National List of Essential Medicines (Rename - } \\
\text { Brazil) }\end{array}$} & \multicolumn{3}{|c|}{$\begin{array}{c}\text { List of Essential Medicines (World Health } \\
\text { Organization) }\end{array}$} \\
\hline & Essentiality & $\begin{array}{c}\text { Pharmacotherapeutic } \\
\text { equivalent }\end{array}$ & Essentiality & Essentiality & $\begin{array}{c}\text { Pharmacotherapeutic } \\
\text { equivalent }\end{array}$ & Essentiality \\
\hline Antiasthmatics & Yes & Not reported & $\begin{array}{c}\text { Not appli- } \\
\text { cable }\end{array}$ & Yes & Not reported & Not applicable \\
\hline Antitussives & Yes & Not reported & $\begin{array}{l}\text { Not appli- } \\
\text { cable }\end{array}$ & Yes & Not reported & Not applicable \\
\hline BZD & Yes & $\begin{array}{l}\text { Intermediate-life BZD } \\
\text { Short-life BZD }\end{array}$ & $\begin{array}{l}\text { No } \\
\text { Yes }\end{array}$ & Yes & $\begin{array}{l}\text { Intermediate-life BZD } \\
\text { Short-life BZD }\end{array}$ & $\begin{array}{l}\text { No } \\
\text { Yes }\end{array}$ \\
\hline Beta-blocker & Yes & $\begin{array}{l}\text { Calcium channel } \\
\text { blocker } \\
\text { Cardioselective BB }\end{array}$ & $\begin{array}{l}\text { Yes } \\
\text { Yes }\end{array}$ & Yes & $\begin{array}{l}\text { Calcium channel blocker } \\
\text { Cardioselective BB }\end{array}$ & $\begin{array}{l}\text { Yes } \\
\text { Yes }\end{array}$ \\
\hline Betamethasone & Yes & Not reported & $\begin{array}{l}\text { Not appli- } \\
\text { cable }\end{array}$ & Yes & Not reported & Not applicable \\
\hline Buprenorphine & No & Not reported & $\begin{array}{l}\text { Not appli- } \\
\text { cable }\end{array}$ & No & Not reported & Not applicable \\
\hline Carteolol & No & $\begin{array}{l}\text { Beta-blockers } \\
\text { Carvedilol } \\
\end{array}$ & $\begin{array}{l}\text { Yes } \\
\text { Yes }\end{array}$ & No & $\begin{array}{l}\text { Beta-blocker } \\
\text { Carvedilol }\end{array}$ & $\begin{array}{l}\text { Yes } \\
\text { No }\end{array}$ \\
\hline Chlorazepate & No & Not reported & $\begin{array}{l}\text { Not appli- } \\
\text { cable }\end{array}$ & No & Not reported & Not applicable \\
\hline Chlordiazepoxide & No & Not reported & $\begin{array}{l}\text { Not appli- } \\
\text { cable }\end{array}$ & No & Not reported & Not applicable \\
\hline Clomethazole & No & Not reported & $\begin{array}{l}\text { Not appli- } \\
\text { cable }\end{array}$ & No & Not reported & Not applicable \\
\hline Codeine & Yes & $\begin{array}{l}\text { Anti-Rheumatic } \\
\text { NSAID }\end{array}$ & $\begin{array}{l}\text { Yes } \\
\text { Yes }\end{array}$ & Yes & $\begin{array}{l}\text { Anti-Rheumatic } \\
\text { NSAID }\end{array}$ & $\begin{array}{l}\text { Yes } \\
\text { Yes }\end{array}$ \\
\hline Dextropropoxyphene & No & \begin{tabular}{|l|} 
Codeine \\
Ibuprofen \\
Paracetamol \\
\end{tabular} & $\begin{array}{l}\text { Yes } \\
\text { Yes } \\
\text { Yes }\end{array}$ & No & \begin{tabular}{|l} 
Codeine \\
Ibuprofen \\
Paracetamol \\
\end{tabular} & $\begin{array}{l}\text { Yes } \\
\text { Yes } \\
\text { Yes }\end{array}$ \\
\hline Diazepam & Yes & Not reported & $\begin{array}{l}\text { Not appli- } \\
\text { cable }\end{array}$ & Yes & Not reported & Not applicable \\
\hline Fentanyl & No & Not reported & $\begin{array}{l}\text { Not appli- } \\
\text { cable }\end{array}$ & Yes & Not reported & Not applicable \\
\hline Halazepam & No & Not reported & $\begin{array}{l}\text { Not appli- } \\
\text { cable }\end{array}$ & No & Not reported & Not applicable \\
\hline Hypnotics & Yes & Z-drugs & No & Yes & Z-drugs & No \\
\hline Meperidine & No & Hydromorphone & No & No & Hydromorphone & No \\
\hline Metformin & Yes & Not reported & $\begin{array}{l}\text { Not appli- } \\
\text { cable }\end{array}$ & Yes & Not reported & Not applicable \\
\hline Methylprednisolone & Yes & Prednisolone & Yes & Yes & Prednisolone & No \\
\hline Mucolytics & Yes & Not reported & $\begin{array}{l}\text { Not appli- } \\
\text { cable }\end{array}$ & Yes & Not reported & Not applicable \\
\hline Nitrofurantoin & Yes & $\begin{array}{l}\text { Cephalosporins } \\
\text { Cotrimoxazole } \\
\text { Trimethoprim } \\
\end{array}$ & $\begin{array}{l}\text { Yes } \\
\text { No } \\
\text { Yes }\end{array}$ & No & $\begin{array}{l}\text { Cephalosporins } \\
\text { Cotrimoxazole } \\
\text { Trimethoprim } \\
\end{array}$ & $\begin{array}{l}\text { Yes } \\
\text { No } \\
\text { Yes }\end{array}$ \\
\hline $\begin{array}{l}\text { Non-selective beta- } \\
\text { blocker }\end{array}$ & Yes & Not reported & $\begin{array}{l}\text { Not appli- } \\
\text { cable }\end{array}$ & Yes & Not reported & Not applicable \\
\hline Pentobarbital & Yes & $\begin{array}{l}\text { Intermediate-life BZD } \\
\text { Short-life BZD }\end{array}$ & $\begin{array}{l}\text { No } \\
\text { Yes }\end{array}$ & Yes & $\begin{array}{l}\text { Intermediate-life BZD } \\
\text { Short-life BZD }\end{array}$ & $\begin{array}{l}\text { No } \\
\text { Yes }\end{array}$ \\
\hline Phenobarbital & Yes & \begin{tabular}{|l} 
Gabapentin \\
Lamotrigine \\
Levetiracetam \\
Valproic acid \\
\end{tabular} & $\begin{array}{l}\text { Yes } \\
\text { Yes } \\
\text { Yes } \\
\text { Yes }\end{array}$ & Yes & $\begin{array}{l}\text { Gabapentin } \\
\text { Lamotrigine } \\
\text { Levetiracetam } \\
\text { Valproic acid } \\
\end{array}$ & $\begin{array}{l}\text { No } \\
\text { Yes } \\
\text { No } \\
\text { Yes }\end{array}$ \\
\hline
\end{tabular}




\begin{tabular}{|c|c|c|c|c|c|c|}
\hline \multirow[b]{2}{*}{$\begin{array}{c}\text { Inappropriate drugs } \\
\text { and pharmacological } \\
\text { classes }\end{array}$} & \multicolumn{3}{|c|}{\begin{tabular}{|c|}
$\begin{array}{c}\text { National List of Essential Medicines (Rename - } \\
\text { Brazil) }\end{array}$ \\
\end{tabular}} & \multicolumn{3}{|c|}{$\begin{array}{c}\text { List of Essential Medicines (World Health } \\
\text { Organization) }\end{array}$} \\
\hline & Essentiality & $\begin{array}{c}\text { Pharmacotherapeutic } \\
\text { equivalent }\end{array}$ & Essentiality & Essentiality & $\begin{array}{c}\text { Pharmacotherapeutic } \\
\text { equivalent }\end{array}$ & Essentiality \\
\hline Prednisolone & Yes & Not reported & $\begin{array}{l}\text { Not appli- } \\
\text { cable }\end{array}$ & No & Not reported & Not applicable \\
\hline Propranolol & Yes & $\begin{array}{l}\text { ACE inhibitors } \\
\text { Cardioselective beta- } \\
\text { blockers } \\
\text { Diuretics } \\
\end{array}$ & $\begin{array}{l}\text { Yes } \\
\text { Yes } \\
\text { Yes }\end{array}$ & Yes & $\begin{array}{l}\text { ACE inhibitors } \\
\text { Cardioselective beta- } \\
\text { blockers } \\
\text { Diuretics } \\
\end{array}$ & $\begin{array}{l}\text { Yes } \\
\text { Yes } \\
\text { Yes }\end{array}$ \\
\hline Quazepam & No & Not reported & $\begin{array}{l}\text { Not appli- } \\
\text { cable }\end{array}$ & No & Not reported & Not applicable \\
\hline Selective beta-blocker & Yes & Not reported & $\begin{array}{l}\text { Not appli- } \\
\text { cable }\end{array}$ & Yes & Not reported & Not applicable \\
\hline Systemic corticosteroids & Yes & Inhaled corticosteroids & Yes & Yes & Inhaled corticosteroids & Yes \\
\hline Theophylline & No & Not reported & $\begin{array}{l}\text { Not appli- } \\
\text { cable }\end{array}$ & No & Not reported & Not applicable \\
\hline Thiopental & $\mathrm{No}$ & Short-life BZD & Yes & $\mathrm{No}$ & Short-life BZD & Yes \\
\hline
\end{tabular}

ACE inhibitors: Angiotensin converting enzyme inhibitors; BZD: benzodiazepines; NSAID: nonsteroidal antiinflammatory drugs.

Despite there is no therapeutic management proposal for the potentially inappropriate medications involved in 15 drug interactions, the tools reported some options for managing betablockers and benzodiazepines. Regarding betablockers, the tools recommended the replacement for cardioselective beta-blockers, calcium channel blockers, angiotensin-converting enzyme inhibitors, and angiotensin II type I receptor blockers or another class of antihypertensive drugs. For benzodiazepines, it is recommended the use of short or intermediate half-life benzodiazepines. The rationale and therapeutic management reported in the tools for the drug interactions, and potentially inappropriate medication are described in Table 2.

Eight tools reported 17 potentially inappropriate medications with concerns for the respiratory system. The drugs most frequently reported were phenobarbital $(n=3)$, propranolol $(n=2)$, and theophylline $(\mathrm{n}=2)$, all associated with respiratory depression, exacerbation of the respiratory disorder, and induction of asthmatic attacks. Clinical monitoring of possible adverse drug events from phenobarbital use is recommended and, when possible, the use of antiepileptics (lamotrigine, valproic acid, levetiracetam, and gabapentin) is preferable. Angiotensin-converting enzyme inhibitors, angiotensin II type I receptor blockers, selective beta-blockers, and diuretics should be considered instead of propranolol. Besides, carvedilol may be the best choice in heart failure complicated by COPD. No pharmacotherapeutic equivalent was reported for theophylline, however, cardiac function monitoring is strongly recommended due to this drug's narrow therapeutic range. When possible, monitoring this drug's use to identify possible adverse drug events and starting non-pharmacological treatment was recommended (Table 3 and Figure 1).

Twenty-two drugs and nine pharmacological classes were reported in drug interaction and/ or associated with adverse drug events with respiratory disorders. Among them, nine and eight drugs and nine pharmacological classes are standard as essential in the world (WHO) and Brazil (Rename), respectively. Besides, the tools proposed 22 therapeutic equivalents for the potentially inappropriate medication identified, being 18 standards as essential by Rename and 16 by WHO (Tables 3 and 4).

\section{DISCUSSION}

In our systematic scoping review, 19 tools reported 21 drug interactions, and 17 potentially inappropriate medications (16 drugs and one pharmacological class) with concerns related to three respiratory disorders (asthma, COPD, and respiratory failure). The most frequent pharmacological classes reported were beta-blockers and benzodiazepines. The tools recommended beta-blockers management in cardiovascular disease treatment with other antihypertensive classes and short or intermediate half-life benzodiazepines. 
At the beginning of the pandemic, studies suggested that angiotensin-converting enzyme inhibitors and angiotensin II type I receptor blockers could be risk factors for COVID-19 infection (24). Such hypotheses were based on the fact that high blood pressure was the most prevalent comorbidity among patients diagnosed with COVID-19 infection $(25,26)$, and the virus binding to angiotensin-converting enzyme-2 during the infection process (27). These hypotheses were widely publicized in the media, which led some prescribers to replace angiotensin-converting enzyme inhibitors and angiotensin II type I receptor blockers for other antihypertensive drugs, such as calcium channel blockers, due to the class is not associated with increased expression of angiotensinconverting enzyme-2 (24). Moreover, patients began to drop the treatment with angiotensinconverting enzyme inhibitors and angiotensin II type I receptor blockers on their own (28), which led to uncontrolled high blood pressure and other cardiovascular diseases, increasing the risks of COVID-19 infection (10).

However, the association between the use of angiotensin-converting enzyme inhibitors and angiotensin II type I receptor blockers and the risk of infection by COVID-19 was not confirmed $(29,30)$. This confusion can be justified because cardiovascular comorbidities may be linked to COVID-19 infection. Being often prescribed to treat such conditions, these pharmacological classes may be considered a confounding factor to COVID-19 infection (31).

Our systematic scoping review did not identify angiotensin-converting enzyme inhibitors and angiotensin II type I receptor blockers as potentially inappropriate medications, nor associated with adverse drug events related to respiratory disorders. Besides, these pharmacological classes are recommended by the tools for managing beta-blockers use, being considered safer options for the elderly in general and with respiratory disorders. However, studies suggest that the use of cardioselective beta-blockers in patients with COPD or asthma is not associated with severe adverse drug events (32-34). That risk can vary according to cardioselectivity, dose, and duration of the elderly's exposure to the medication (35).

From another perspective, chloroquine or hydroxychloroquine, drugs that are being widely studied for prophylaxis and COVID-19 treatment
$(36,37)$, have not been identified as potentially inappropriate medications or involved in drug interactions with respiratory disorders. However, chloroquine or hydroxychloroquine are indicated to treat rheumatological, immunological, and infectious diseases, constituting an off-label use in the infection of COVID-19. Besides, there is no evidence of high quality regarding the real risk/benefit of this use. The higher frequency of use and therapeutic overdose may be associated with significant adverse drug events (e.g., cardiomyopathy (38), prolongation of the QT interval (39), and psychiatric manifestations (e.g., depression, insomnia, and psychosis) (40). Specifically, in Canadian elderly people with COVID-19, Ross et al. (41) identified that 58.9\% were receiving one or more home medications that could potentially interact with hydroxychloroquine. Of these, $43.2 \%$ were flagged as potentially inappropriate medication by the MedSafer tool (41).

Benzodiazepines, other pharmacological classes frequently involved in drug interactions with respiratory disorders, are widely prescribed to manage anxiety and insomnia in older adults (42). Nevertheless, the long term use of benzodiazepines has been associated with a high risk of respiratory depression $(43,44)$ and dementia, despite some uncertainty (45). The management of benzodiazepines is limited; however, the monitoring of possible adverse drug events and deprescription could be an interesting process.

Therefore, the drug therapy assessment and safety risks in the elderly with respiratory disorders are essential to promote patient security since drug interactions may reduce the effectiveness of the inhaled medications and increase the risk of adverse drug events (46). Furthermore, there are other issues to be considered, such as fewer diagnoses of respiratory disorders, difficulty in acquiring drugs for the disease control, and management in low-income patients (47), in addition to treatment adherence failures $(48,49)$. The failure to adhere to treatment is related to several factors, difficulty in acquiring the medication, and knowledge lacking proper medication use (48). Consequently, these factors are related to uncontrolled respiratory disorders, which increases the cost of hospitalizations (e.g., mechanical ventilation due to respiratory failure $(1,50))$, and reduces the life quality of the elderly $(47,48)$.

In this context, an important strategy to identify and solve drug-related problems and 
adherence failures would be the medication therapy management service that allows identifying possible drug-related problems and the medication experience of the patient and/or caregiver/relatives concerning the drugs in use (51). Furthermore, considering COVID-19 times, it is necessary to identify and monitor the elderly with possible worse prognosis related to COVID-19 for a targeted and specific approach that can be implemented (7).

Hence, considering the risks of using potentially inappropriate medications by older adults with respiratory disorders and the possible health problems related to adverse drug events and COVID-19, the knowledge of drug interactions and potentially inappropriate medications contributes to the adequacy of clinical monitoring, discontinuation, and deprescription of these medications (52). Still, the deprescription contributes to greater adherence to pharmacological treatment and reduces medication errors, possible adverse drug events and costs (53), thus promoting patient safety and the rational use of drugs by the elderly with respiratory disorders (54).

Our study did not aim to evaluate the correlation between potentially inappropriate medications uses and worsening of the prognosis of COVID-19; however, it highlights the importance, in COVID-19 times, of redoubling the care of the elderly with respiratory disorders and in use of potentially inappropriate medications. The assessment regarding the worsening of the COVID-19 prognosis and use of pharmacological classes and drugs identified in this review requires studies specifically designed to identify the presence or absence of this association.

One limitation of this review, as with any systematic search, is that missing studies could exist. However, manual searches were conducted to supplement electronic search limitations. In addition, our systematic scoping review excluded tools containing only implicit criteria.

\section{CONCLUSION}

In conclusion, 19 drug interactions between potentially inappropriate medication and respiratory disorders (asthma, chronic obstructive pulmonary disease, and respiratory failure) were reported. The beta-blockers and benzodiazepines were the most inappropriate pharmacological classes involved in the drug interactions due to the worsening of respiratory disorders and respiratory depression, increasing mucus production, and promoting bronchoconstriction concerning the antagonistic effects in $\mathrm{B} 2$ receptors.

Although studies initially suggested that angiotensin-converting enzyme inhibitors and angiotensin II type I receptor blockers could be associated with COVID-19 risk, such pharmacological classes are not considered potentially inappropriate medications. They are not involved in drug interactions, adverse drug events, or concerns related to respiratory disorders. Moreover, these pharmacological classes are considered safe therapeutic equivalents for the management of beta-blockers.

Therefore, the identification of drug interactions and potentially inappropriate medications, the knowledge of possible adverse drug events, and possible concerns related to the use of these drugs can collaborate to detect elderly people who may have worse prognoses of other respiratory insufficiencies and COVID-19. It can also help implement a care plan targeted and specific for the elderly with respiratory disorders, thus promoting the safety of the geriatric patient.

\section{SOURCES OF FUNDING AND ACKNOWLEDGMENTS}

This work was supported by Conselho Nacional para o Desenvolvimento Científico e Tecnológico (CNPq) [grant number 459461/2014-1]; São Paulo Research Foundation (FAPESP) [grants numbers 2019/01565-8; 2018/07501-9]; and Pró-reitoria de Extensão Universitária e Cultura of São Paulo State University (UNESP). This study was financed in part by the Coordenação de Aperfeiçoamento de Pessoal de Nível Superior - Brasil (CAPES) Finance Code 001.

\section{AUTHORS' CONTRIBUTION}

M.F. designed the study, selected the studies, extracted, and analyzed the data, and wrote and reviewed the paper. G.S. selected the studies, extracted, and analyzed the data, and drafted the paper. R.C.L. designed the study, analyzed the data, and reviewed the paper. P.C.M designed the study and reviewed the paper. All authors developed the manuscript and approved the final version to be submitted. 


\section{COMPETING INTERESTS}

All the authors are aware and agree to this submission and declare no conflict of interest.

\section{REFERENCES}

1. Angus DC. Current and Projected Workforce Requirements for Care of the Critically Ill and Patients With Pulmonary Disease. JAMA. 2000 Dec 6;284(21):2762. DOI: 10.1001/ jama.284.21.2762

2. Thanaviratananich S, Cho S-H, Ghoshal AG, Muttalif ARBA, Lin $\mathrm{H}-\mathrm{C}$, Pothirat $\mathrm{C}$, et al. Burden of respiratory disease in Thailand: Results from the APBORD observational study. Medicine (Baltimore). 2016 Jul;95(28):e4090. DOI: 10.1097/ MD.0000000000004090

3. Wang DY, Ghoshal AG, Bin Abdul Muttalif AR, Lin H-C, Thanaviratananich S, Bagga S, et al. Quality of Life and Economic Burden of Respiratory Disease in Asia-Pacific-AsiaPacific Burden of Respiratory Diseases Study. Value Heal Reg Issues. 2016 May;9:72-7. DOI: 10.1016/j.vhri.2015.11.004

4. Carreiro-Martins P, Gomes-Belo J, Papoila AL, Caires I, Palmeiro T, Gaspar-Marques J, et al. Chronic respiratory diseases and quality of life in elderly nursing home residents. Chron Respir Dis. 2016 Aug;13(3):211-9. DOI: 10.1177/1479972316636990

5. Shahid Z, Kalayanamitra R, McClafferty B, Kepko D, Ramgobin D, Patel R, et al. COVID-19 and Older Adults: What We Know. J Am Geriatr Soc [Internet]. 2020 May 20; 68(5):926-9. DOI: 10.1111/jgs.16472

6. Yang J, Zheng Y, Gou X, Pu K, Chen Z, Guo Q, et al. Prevalence of comorbidities and its effects in patients infected with SARSCoV-2: a systematic review and meta-analysis. Int J Infect Dis. 2020 May; 94:91-5. DOI: 10.1016/j.ijid.2020.03.017

7. von der Thüsen J, Eerden M. Histopathology and genetic susceptibility in COVID-19 pneumonia. Eur J Clin Invest. 2020 Jul 27; 50(7):eci.13259. DOI: https://doi.org/10.1111/eci.13259

8. Arentz M, Yim E, Klaff L, Lokhandwala S, Riedo FX, Chong M, et al. Characteristics and Outcomes of 21 Critically Ill Patients With COVID-19 in Washington State. JAMA. 2020 Apr 28; 323(16):1612. DOI: 10.1001/jama.2020.4326

9. Lake MA. What we know so far: COVID-19 current clinical knowledge and research. Clin Med (Northfield Il). 2020 Mar;20(2):124-7. DOI: 10.7861/clinmed.2019-coron

10. Tadic M, Cuspidi C, Mancia G, Dell'Oro R, Grassi G. COVID-19, hypertension and cardiovascular diseases: Should we change the therapy? Pharmacol Res. 2020 Aug;158:104906. DOI: $10.1016 /$ j.phrs.2020.104906

11. O Riordan D, Aubert CE, Walsh KA, Van Dorland A, Rodondi N, Du Puy RS, et al. Prevalence of potentially inappropriate prescribing in a subpopulation of older European clinical trial participants: a cross-sectional study. BMJ Open. 2018 Mar 22; 8(3):e019003. DOI: 10.1136/bmjopen-2017-019003

12. Wehling M. Multimorbidity and polypharmacy: how to reduce the harmful drug load and yet add needed drugs in the elderly? Proposal of a new drug classification: fit for the aged. J Am Geriatr Soc. 2009 Mar; 57(3):560-1. DOI: 10.1111/j.15325415.2009.02131.x.

13. Forgerini M, Herdeiro MT, Galduróz JCF, Mastroianni P de C. Sao Paulo Med J. 2020 Jun;138(3):216-8. Risk factors associated with drug therapy among elderly people with Alzheimer's disease: a cross-sectional study. DOI: 10.1590/1516-3180.2019.0461. r2.19022020

14. Varallo FR, Costa MA, Mastroianni P de C. Potenciais interações medicamentosas responsáveis por internações hospitalares. Rev Ciencias Farm Basica e Apl. 2013.
15. Mastroianni P de C, Forgerini M. Compliance and Drug Related Problems in probable Alzheimer's disease elderly. Int Psychogeriatrics. 2019;1-2. DOI: 10.1017/S104161021800234X

16. Komagamine J. Prevalence of potentially inappropriate medications at admission and discharge among hospitalised elderly patients with acute medical illness at a single centre in Japan: a retrospective cross-sectional study. BMJ Open. 2018 Jul 19;8(7):e021152. DOI: 10.1136/bmjopen-2017-021152

17. Almeida; LS de, Nascimento; MMG do, Oliveira; DR de, Oliveira; I V., Detoni; LB, Caux; TR de, et al. Potentially inappropriate medication use profile among older people with chronic obstructive pulmonary disease. Rev Ciências da Saúde Básica e Apl. October 2019;2(1):29-42.

18. Forgerini M, Schiavo G, Lucchetta RC, Mastroianni P de C. Drug interactions for elderly people with mental and behavioral disorders: a systematic scoping review. Arch Gerontol Geriatr. 2020; DOI: 10.1016/j.archger.2020.104283

19. The Joanna Briggs Institute. Summary for Policymakers. In: Intergovernmental Panel on Climate Change, editor. Climate Change 2013 - The Physical Science Basis. Cambridge: Cambridge University Press; 2015. 1-30p.

20. Higgins JPT, Thomas J, Chandler J, Cumpston M, Li T, Page MJ WV (editors). Cochrane Handbook for Systematic Reviews of Interventions version 6.0 (updated July 2019). [Internet]. 2019. Available from: https://training.cochrane.org/handbook

21. Tricco AC, Lillie E, Zarin W, O’Brien KK, Colquhoun H, Levac D, et al. PRISMA Extension for Scoping Reviews (PRISMAScR): Checklist and Explanation. Ann Intern Med. 2018 Oct 2;169(7):467.

22. Schiavo G, Lucchetta RC, Forgerini M, Mastroianni P de C. Assessment tool for potentially inappropriate medication use in the elderly: a scoping review protocol. Rev Ciências Farm Básica e Apl. 2018;39:e637.

23. Lucchetta R. Potentially inappropriate medications criteria-based tools for the elderly: a systematic scoping review. OSF. 2020; DOI: 10.17605/OSF.IO/EUVR2

24. Fang L, Karakiulakis G, Roth M. Are patients with hypertension and diabetes mellitus at increased risk for COVID-19 infection? Lancet Respir Med. 2020 Apr;8(4):e21. DOI: 10.1016/S22132600(20)30116-8

25. Guan W, Liang W, Zhao Y, Liang H, Chen Z, Li Y, et al. Comorbidity and its impact on 1590 patients with COVID-19 in China: a nationwide analysis. Eur Respir J. 2020 May;55(5):2000547. DOI: 10.1183/13993003.00547-2020

26. Zhou F, Yu T, Du R, Fan G, Liu Y, Liu Z, et al. Clinical course and risk factors for mortality of adult inpatients with COVID-19 in Wuhan, China: a retrospective cohort study. Lancet. 2020 Mar;395(10229):1054-62. DOI: 10.1016/S0140-6736(20)30566-3

27. Chen Y, Guo Y, Pan Y, Zhao ZJ. Structure analysis of the receptor binding of 2019-nCoV. Biochem Biophys Res Commun. 2020 Apr;525(1):135-40. DOI: 10.1016/j.bbrc.2020.02.071

28. Williams B, Zhang Y. Hypertension, renin-angiotensinaldosterone system inhibition, and COVID-19. Lancet. 2020 May;395(10238):1671-3. DOI: 10.1016/S0140-6736(20)31131-4

29. Reynolds HR, Adhikari S, Pulgarin C, Troxel AB, Iturrate E, Johnson SB, et al. Renin-Angiotensin-Aldosterone System Inhibitors and Risk of Covid-19. N Engl J Med. 2020 May 1;NEJMoa2008975. DOI: 10.1056/NEJMoa2008975

30. Bean; DM, Kraljevic; Zeljko, Searle; T, Bendayan; R, Pickles1; A, Folarin; A, et al. Treatment with ACE-inhibitors is associated with less severe disease with SARS-Covid-19 infection in a multi-site UK acute Hospital Trust. medRxiv. 2020; DOI: 10.1101/2020.04.07.20056788

31. de Abajo FJ, Rodríguez-Martín S, Lerma V, Mejía-Abril G, Aguilar M, García-Luque A, et al. Use of renin-angiotensinaldosterone system inhibitors and risk of COVID-19 requiring admission to hospital: a case-population study. Lancet. 2020 May;395(10238):1705-14. DOI: 10.1016/S0140-6736(20)31030-8 
32. Salpeter SR, Ormiston TM, Salpeter EE. Cardioselective betablockers for chronic obstructive pulmonary disease. Cochrane Database Syst Rev. 2005 Oct 19; DOI: 10.1002/14651858. CD003566.pub2

33. Morales DR, Jackson C, Lipworth BJ, Donnan PT, Guthrie B. Adverse Respiratory Effect of Acute $\beta$-Blocker Exposure in Asthma. Chest. 2014 Apr;145(4):779-86. DOI: 10.1378/ chest.13-1235

34. Duffy S, Marron R, Voelker H, Albert R, Connett J, Bailey W, et al. Effect of beta-blockers on exacerbation rate and lung function in chronic obstructive pulmonary disease (COPD). Respir Res. 2017 Dec 19;18(1):124. DOI: 10.1186/s12931-017-0609-7

35. Morales DR, Lipworth BJ, Donnan PT, Jackson C, Guthrie B. Respiratory effect of beta-blockers in people with asthma and cardiovascular disease: population-based nested case control study. BMC Med. 2017 Dec 27;15(1):18. DOI: 10.1186/s12916017-0781-0

36. Hernandez A V., Roman YM, Pasupuleti V, Barboza JJ, White CM. Hydroxychloroquine or Chloroquine for Treatment or Prophylaxis of COVID-19: A Living Systematic Review. Ann Intern Med. 2020 May;M20-2496. DOI: 10.7326/M20-2496

37. Patel TK, Barvaliya M, Kevadiya BD, Patel PB, Bhalla HL. Does Adding of Hydroxychloroquine to the Standard Care Provide Any Benefit in Reducing the Mortality Among COVID-19 Patients?: A Systematic Review. J Neuroimmune Pharmacol. 2020; DOI: 10.1007/s11481-020-09930-x

38. Al-Bari MAA. Chloroquine analogues in drug discovery: new directions of uses, mechanisms of actions and toxic manifestations from malaria to multifarious diseases. J Antimicrob Chemother. 2015 Jun 1;70(6):1608-21. DOI: 10.1093/jac/dkv018

39. Juurlink DN. Safety considerations with chloroquine, hydroxychloroquine and azithromycin in the management of SARS-CoV-2 infection. Can Med Assoc J [Internet]. 2020 Apr 27;192(17):E450-3. Available from: http://www.cmaj.ca/lookup/ doi/10.1503/cmaj.200528

40. Mascolo A, Berrino PM, Gareri P, Castagna A, Capuano A, Manzo C, et al. Neuropsychiatric clinical manifestations in elderly patients treated with hydroxychloroquine: a review article. Inflammopharmacology. 2018 Oct 9;26(5):1141-9. DOI: 10.1007/ s10787-018-0498-5

41. Ross SB, Wilson MG, Papillon-Ferland L, Elsayed S, Wu PE, Battu K, et al. COVID-SAFER: Deprescribing Guidance for Hydroxychloroquine Drug Interactions in Older Adults. J Am Geriatr Soc. 2020 Aug 30;68(8):1636-46. DOI: 10.1111/jgs.16623

42. Kroll DS, Nieva HR, Barsky AJ, Linder JA. Benzodiazepines are Prescribed More Frequently to Patients Already at Risk for Benzodiazepine-Related Adverse Events in Primary Care. J Gen Intern Med. 2016 Sep 13;31(9):1027-34. DOI: 10.1007/s11606016-3740-0

43. Baillargeon J, Singh G, Kuo Y-F, Raji MA, Westra J, Sharma G. Association of Opioid and Benzodiazepine Use with Adverse Respiratory Events in Older Adults with Chronic Obstructive Pulmonary Disease. Ann Am Thorac Soc. 2019 Oct;16(10):124551. DOI: 10.1513/AnnalsATS.201901-024OC.

44. Nakafero G, Sanders RD, Nguyen-Van-Tam JS, Myles PR. Association between benzodiazepine use and exacerbations and mortality in patients with asthma: a matched case-control and survival analysis using the United Kingdom Clinical Practice Research Datalink. Pharmacoepidemiol Drug Saf. 2015 Aug;24(8):793-802. DOI: 10.1002/pds.3799

45. Lucchetta RC, da Mata BPM, Mastroianni P de C. Association between Development of Dementia and Use of Benzodiazepines: A Systematic Review and Meta-Analysis. Pharmacother J Hum Pharmacol Drug Ther. 2018 Oct;38(10):1010-20. DOI: 10.1002/ phar. 2170

46. Scichilone N. Comorbidities of Lung Disease in the Elderly. Clinics in Geriatric Medicine. 2017. DOI: 10.1016/j. cger.2017.06.010.
47. Leal LF, Bertoldi AD, Menezes AMB, Borges RB, Mengue SS, Gazzana MB, et al. Indicação, acesso e utilização de medicamentos para doenças respiratórias crônicas no Brasil: resultados da Pesquisa Nacional sobre Acesso, Utilização e Promoção do Uso Racional de Medicamentos no Brasil (PNAUM), 2014. Cad Saude Publica. 2018 Oct 11; 34(10). DOI: 10.1590/0102-311x00208217

48. Scichilone N, Ventura MT, Bonini M, Braido F, Bucca C, Caminati $\mathrm{M}$, et al. Choosing wisely: practical considerations on treatment efficacy and safety of asthma in the elderly. Clin Mol Allergy. 2015 Dec 22;13(1):7. DOI: 10.1186/s12948-015-0016-x

49. Mäkelä MJ, Backer V, Hedegaard M, Larsson K. Adherence to inhaled therapies, health outcomes and costs in patients with asthma and COPD. Respir Med. 2013 Oct;107(10):1481-90. DOI: 10.1016/j.rmed.2013.04.005

50. Muir J-F, Lamia B, Molano C, Cuvelier A. Respiratory Failure in the Elderly Patient. Semin Respir Crit Care Med. 2010 Oct 12;31(05):634-46. DOI: 10.1055/s-0030-1265903.

51. Shoemaker SJ, Ramalho de Oliveira D. Understanding the meaning of medications for patients: The medication experience. Pharm World Sci. 2007 Nov 21;30(1):86-91. DOI: 10.1007/ s11096-007-9148-5

52. O'Mahony D, Gallagher P, Lavan A. Methods to reduce prescribing errors in elderly patients with multimorbidity. Clin Interv Aging. 2016 Jun;11:857. DOI: 10.2147/CIA.S80280

53. Dills H, Shah K, Messinger-Rapport B, Bradford K, Syed Q. Deprescribing Medications for Chronic Diseases Management in Primary Care Settings: A Systematic Review of Randomized Controlled Trials. J Am Med Dir Assoc. 2018 Nov;19(11):923935.e2. DOI: 10.1016/j.jamda.2018.06.021

54. Gabe ME, Murphy F, Davies GA, Russell IT, Jordan S. Medication Monitoring in a Nurse-Led Respiratory Outpatient Clinic: Pragmatic Randomised Trial of the West Wales Adverse Drug Reaction Profile. Scheurer M, editor. PLoS One. 2014 May 5;9(5):e96682. DOI: 10.1371/journal.pone.0096682

55. Fick DM, Cooper JW, Wade WE, Waller JL, Maclean JR, Beers MH. Updating the Beers Criteria for Potentially Inappropriate Medication Use in Older Adults. Arch Intern Med. 2003 Dec 8;163(22):2716. DOI: 10.1001/archinte.163.22.2716

56. Winit-Watjana W, Sakulrat P, Kespichayawattana J. Criteria for high-risk medication use in Thai older patients. Arch Gerontol Geriatr. 2008 Jul;47(1):35-51. DOI: 10.1016/j.archger.2007.06.006

57. Kim DS, Heo SI, Lee SH. Development of a List of Potentially Inappropriate Drugs for the Korean Elderly Using the Delphi Method. Healthc Inform Res. 2010;16(4):231. DOI: 10.4258/ hir.2010.16.4.231

58. Mimica Matanović S, Vlahovic-Palcevski V. Potentially inappropriate medications in the elderly: a comprehensive protocol. Eur J Clin Pharmacol. 2012 Aug 24;68(8):1123-38. DOI: 10.1007/s00228-012-1238-1

59. Mann E, Böhmdorfer B, Frühwald T, Roller-Wirnsberger RE, Dovjak P, Dückelmann-Hofer C, et al. Potentially inappropriate medication in geriatric patients: the Austrian consensus panel list. Wien Klin Wochenschr. 2012 Mar 2;124(5-6):160-9. DOI: 10.1007/s00508-011-0061-5

60. Fialová D. Potentially Inappropriate Medication Use Among Elderly Home Care Patients in Europe. JAMA. 2005 Mar 16;293(11):1348. DOI: 10.1001/jama.293.11.1348.

61. Clyne B, Bradley MC, Hughes CM, Clear D, McDonnell R, Williams D, et al. Addressing potentially inappropriate prescribing in older patients: development and pilot study of an intervention in primary care (the OPTI-SCRIPT study). BMC Health Serv Res. 2013 Dec 14;13(1):307. DOI: 10.1186/14726963-13-307

62. Delgado Silveira E, Montero Errasquín B, Muñoz García M, Vélez-Díaz-Pallarés M, Lozano Montoya I, Sánchez-Castellano C, et al. Mejorando la prescripción de medicamentos en las personas mayores: una nueva edición de los criterios STOPP- 
START. Rev Esp Geriatr Gerontol. 2015 Mar;50(2):89-96. DOI: 10.1016/j.regg.2014.10.005

63. O'Mahony D, O'Sullivan D, Byrne S, O'Connor MN, Ryan C, Gallagher P. STOPP/START criteria for potentially inappropriate prescribing in older people: version 2. Age Ageing. 2014 Oct 16;44(2):213-8. DOI: 10.1093/ageing/afu145

64. Tommelein E, Petrovic M, Somers A, Mehuys E, van der Cammen T, Boussery K. Older patients' prescriptions screening in the community pharmacy: development of the Ghent Older People's Prescriptions community Pharmacy Screening (GheOP $\left.{ }^{3} \mathrm{~S}\right)$ tool. J Public Health (Bangkok). 2016 Jun;38(2):e158-70. DOI: 10.1093/pubmed/fdv090

65. Renom-Guiteras A, Meyer G, Thürmann PA. The EU(7)-PIM list: a list of potentially inappropriate medications for older people consented by experts from seven European countries. Eur J Clin Pharmacol. 2015 Jul 14;71(7):861-75. DOI: 10.1007/s00228-0151860-9

66. Kojima T, Mizukami K, Tomita N, Arai H, Ohrui T, Eto M, et al. Screening Tool for Older Persons' Appropriate Prescriptions for Japanese: Report of the Japan Geriatrics Society Working Group on "Guidelines for medical treatment and its safety in the elderly.” Geriatr Gerontol Int. 2016 Sep;16(9):983-1001. DOI: 10.1111/ggi.12890

67. Poudel A, Ballokova A, Hubbard RE, Gray LC, Mitchell CA, Nissen LM, et al. Algorithm of medication review in frail older people: Focus on minimizing the use of high-risk medications. Geriatr Gerontol Int. 2016 Sep;16(9):1002-13. DOI: 10.1111/ ggi.12589

68. Oliveira MG, Amorim WW, Oliveira CRB, Coqueiro HL, Gusmão LC, Passos LC. Consenso brasileiro de medicamentos potencialmente inapropriados para idosos. Geriatr Gerontol Aging. 2017 Dec;10(4):168-81. DOI: 10.5327/Z2447211520161600054
69. Kim M-Y, Etherton-Beer C, Kim C-B, Yoon JL, Ga H, Kim HC, et al. Development of a Consensus List of Potentially Inappropriate Medications for Korean Older Adults. Ann Geriatr Med Res. 2018 Sep 30;22(3):121-9. DOI: 10.4235/ agmr.2018.22.3.121

70. Marzi MM, Pires MS, Quaglia NB. Ingredientes Farmacéuticos Activos Potencialmente Inapropiados en Adultos Mayores: Lista IFAsPIAM: Panel de Consenso Argentino. Value Heal Reg Issues. 2018; DOI: 10.1016/j.vhri.2017.10.002

71. Samaranayake NR, Balasuriya A, Fernando GH, Samaraweera D, Shanika LGT, Wanigasuriya JKP, et al. 'Modified STOPPSTART criteria for Sri Lanka'; translating to a resource limited healthcare setting by Delphi consensus. BMC Geriatr. 2019 Dec 22;19(1):282. DOI: 10.1186/s12877-019-1293-x

72. Gonzalez-Colaço Harmand M, Aldea-Perona AM, BoadaFernández del Campo C, Areosa-Sastre A, Rodríguez-Jiménez C, García Sánchez-Colomer M, et al. Spanish list of potentially inappropriate drugs in the elderly (ES-PIA project). Eur J Clin Pharmacol. 2019 Aug 8;75(8):1161-76. DOI: 10.1007/s00228019-02684-3

73. Chang C-B, Lai H-Y, Hwang S-J, Yang S-Y, Wu R-S, Chang L-Y, et al. The updated PIM-Taiwan criteria: a list of potentially inappropriate medications in older people. Ther Adv Chronic Dis. 2019 Jan 5;10:204062231987960. DOI: $10.1177 / 2040622319879602$ 